\title{
"Developing a model for Syariah banking acceptance among Non-Moslem majority population: a case study from Bali, Indonesia"
}

\begin{tabular}{|c|c|}
\hline AUTHORS & $\begin{array}{l}\text { Wahyuniati Hamid (D https://orcid.org/0000-0003-1307-604X } \\
\text { R https://publons.com/researcher/S-7720-2018 }\end{array}$ \\
\hline ARTICLE INFO & $\begin{array}{l}\text { Wahyuniati Hamid (2018). Developing a model for Syariah banking acceptance } \\
\text { among Non-Moslem majority population: a case study from Bali, Indonesia. } \\
\text { Banks and Bank Systems, 13(3), 134-140. doi:10.21511/bbs.13(3).2018.13 }\end{array}$ \\
\hline DOI & http://dx.doi.org/10.21511/bbs.13(3).2018.13 \\
\hline RELEASED ON & Thursday, 04 October 2018 \\
\hline RECEIVED ON & Tuesday, 07 August 2018 \\
\hline \multirow[t]{2}{*}{ ACCEPTED ON } & Wednesday, 26 September 2018 \\
\hline & $(\mathrm{cc}) \mathrm{EY}$ \\
\hline LICENSE & $\begin{array}{l}\text { This work is licensed under a Creative Commons Attribution } 4.0 \text { International } \\
\text { License }\end{array}$ \\
\hline JOURNAL & "Banks and Bank Systems" \\
\hline ISSN PRINT & $1816-7403$ \\
\hline ISSN ONLINE & $1991-7074$ \\
\hline PUBLISHER & LLC "Consulting Publishing Company "Business Perspectives" \\
\hline FOUNDER & LLC "Consulting Publishing Company "Business Perspectives" \\
\hline & $\begin{array}{l}\text { ニ-: } \\
\text { ニE:- }\end{array}$ \\
\hline NUMBER OF REFERENCES & NUMBER OF FIGURES \\
\hline 26 & 0 \\
\hline
\end{tabular}

(C) The author(s) 2021. This publication is an open access article. 


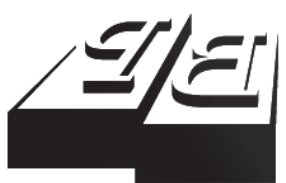

BUSINESS PERSPECTIVES

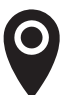

LLC "CPC "Business Perspectives" Hryhorii Skovoroda lane, 10, Sumy, 40022, Ukraine

www.businessperspectives.org

Received on: $7^{\text {th }}$ of August, 2018 Accepted on: $26^{\text {th }}$ of September, 2018

(c) Wahyuniati Hamid, 2018

Wahyuniati Hamid, Lecturer, Doctorate, University of Halu Oleo Kendari, Indonesia.

\begin{abstract}
The study intends to explore the acceptance model of Syariah banking in Bali, Indonesia. It considers that local values, especially menyama-braya, are one of the local wisdoms, and they might encourage people to accept Syariah banks, since Syariah banking emphasizes harmonious relations. Environment marketing theory is useful to explain the importance of local values. Perceived benefit and fairness are thought as perceived values of Islamic banks. Quantitative approach is applied to find relationships between menyama-braya, perceived benefit, and perceived fairness and acceptance model. It follows Malhotra (1993) for sample size, and applies Smart PLS 3 for statistical analysis. The study conceives that menyama-braya as one of the local wisdoms does have a significant effect on the acceptance, while perceived benefit does not. Perceived fairness is seen to have a direct effect on the acceptance. Perceived benefit and perceived fairness both have moderating effect on the relationship between menyama-braya and the acceptance. Managers and employers of Islamic banks should consider relevant local values to strengthen their institutional acceptance among non-Moslem majority population. The study is among the few that include local value in the acceptance model, and the first that attends Islamic banking in non-Moslem majority population.
\end{abstract}

Keywords

JEL Classification menyama-braya, perceived benefit, perceived fairness, Syariah banking acceptance

\section{INTRODUCTION}

In Bali, there are nine Syariah branch banks with Rp 1.4 trillion of total assets. Public deposit in Syariah banking reaches 733 billion and public credit reaches Rp 1.4 trillion. Within only two years (20122014), the number increases by 57.6 percent of which public deposit is 30.19 percent and credit 58.6 percent (MES, 2014).

The whole assets of Syariah banking has reached Rp 454 billion or increased as much as $127.21 \%$. This high growth has been due to increasing number of new banks entering to the Syariah market in Bali. Besides, Syariah banking has also succeeded in attracting people to its services commonly perceived as offering more benefit to consumers compared to conventional banking (Bisnis Jabar, 2011).

As an island rich in famous tourism sites, Bali is crowded by international banks which also stand out for their Syariah services such as Citibank, HSBC, ABN-AMRO, Deutsche Bank, and Bank Victoria Syariah. ANZ Australia has initiated the Syariah service by opening its Syariah unit represented by its first ANZ International Modaraba, Ltd. Japan, Korea and the Netherlands have prepared their Syariah banks to operationalize in 
Bali (Kompasiana, 2014). This trend at least reveals two facts. First, Syariah system has a great potential to grow related to its acceptability by Balinese people. Second, Syariah system is not limited to the religion issue, it might relate to universal values such as fairness, no exploitation, more benefits offering, and transparency. The example is Syariah Victoria Bank where majority of the staff are non-Moslems, and Islamic Bank International of Denmark in Luxemberg where all managing directors are non-Moslems. It indicates that all involved in Syariah transaction are not necessarily Moslems. It implies that Syariah issue is not about Islam but rather a typical transaction system. There is a wide spread for benefit offered to consumers between Syariah banking and conventional one in financing commercial products.

The bulk of Syariah banking customers in Bali are non-Moslems, according to the head of Financial Service Authority of Bali Province. 55 percent of Balinese creditors are non-Moslems, while only 45 percent are Moslems.

This development reveals that Syariah banking is not only for Moslems, but has universal applicability instead. Syariah banks do not serve as a threat to Balinese economy and Hindu values, to which most Balinese people adhere. In fact, there is a heightened belief in Syariah bank's important contribution to all people's welfare. Moreover, their officials often emphasize that Syariah banks do not pertain to a specific religion, as they only offer a more social and fair system of transaction that grasps universal values applicable to all people.

Interestingly, local wisdom might support the existence of Syariah banking in Bali. The existence of Balinese local wisdom might partially explain the growth of Syariah banking. Especially, local wisdom of menyama-braya might be pretty much useful for the emergence of social harmony in Bali, and serve as an essential absorber for a potential conflict. Menyama-braya enables Balinese people to consider non-Balinese people whose religions are not Hindu as family.

Menyama-braya emphasizes that familial relationship holds different people together. All people living in Bali can be said as one family regardless of their origins and religion. The philosophy of menyama-braya derives from two principles thought by Hindu religion, that is tattwmasi (I am you), and Vasudewam Kuthumbakam emphasizing equality that all individuals living in one place are held together as one family.

Local wisdom is a cultural capital developed in a society based on its experience or provided by prior generation to settle common issue it often faces. It comprises local ideas with wise, thoughtful, and goodness characteristics implanted and followed by society. In this way, local wisdom might be a reference to which people should behave, a base to maintain social bond, and a guidance whenever a potential conflict starts to emerge.

The other is benefiting that Syariah banking offers. Financing from Syariah banking offers more benefits to consumers compared to conventional banking. Cumulating data has shown that increasing people are attracted to Syariah banking to finance the commercial product they buy on installment system. Since Syariah banking does not put interest calculation in accruing manner, more benefits often go to consumers.

\section{LITERATURE REVIEW}

\subsection{Theoretical review and preposition building}

The technology acceptance model (TAM) introduced by Davis (1989) is applied to understand user acceptance and usage of information technology. The model originally contained two constructs: perceived ease of use and perceived usefulness. Perceived ease of use is a degree to which a user believes a particular technology is effortless to use (Davis, 1989). Perceived usefulness refers to a degree to which the user believes technology will increase his or her job performance (Davis, 1989). These two constructs are predictors of the acceptance of technology.

Drawing on the model above, the present study develops a model of Syariah banking acceptance among non-Moslem majority population such as 
Balinese people, comprising three constructs, that is perceived benefit, perceived fairness, and menyawa-braya. Concerning perceived benefit as part of value, values provide a basic orientation that directs the perception and attitude. Rokeach (1973) defines value as "an enduring belief that a specific mode of conduct is personally or socially preferable to an opposite or converse mode of conductor end state of existence". It is used interchangeably with shared beliefs, cultural biases, morality, and worldview. Values determine an individual's way of responding to controversies over issues. To explain the role of value, the study applies two theories, namely social exchange theory and marketing environment.

\subsection{Social exchange theory}

This theory argues that an individual will leave a relationship when he/she perceives the costs of the relationship as outweighing the perceived benefits (Emerson, 1962). According to Blau (1964), social exchange is a reciprocal interaction among individuals that mutually benefits the involved parties. Individuals in these exchanges expect rewards from community in which they participate, or from institution with which they make transaction. As social exchange theory in Syariah banking is concerned, many scholars cite perceived benefit and fairness as main characteristics of Syariah banking.

Regarding to advantages of Syariah banks, a Syariah accountancy researcher ever cited that Syariah banking offers more monetary benefits than its counterpart to consumers (Kompasiana, 2014). Consumers seek to receive economic advantages from a relationship with a service provider (Gwinner et al., 1998). Gwinner et al. (1998) illustrated the importance of monetary benefits when developing a relationship with a service company. Beside more promise, Syariah banking is also recognized of its preference in channeling public savings to businesses that bring positive effects to society, not those that are otherwise such as cigarettes, alcohol drinking and the likes. More interestingly, Shariah banking conforms to truth principle in all transactions based on halal standards (Shiddiqh), conveys any information necessary to consumers (Tabligh), applies a good will-based management with care of owners' and businesses' interests that assures trustworthiness, and manages responsiveness and professionalism that satisfy and bring advantages to all concerned parties (Fathanah). These three advantages, beside policy of channeling public savings to socially approved businesses, and morality spirit together serve as its distinctive attractiveness that separates it from conventional one.

Regarding perceived fairness, Syariah economy contains principles of fairness, honesty, transparence, anti-corruption and anti-exploitation. In essence, Syariah economic main missions are to hold strongly moral values in business activities, and to achieve welfare and prosperity in fair manner. This fairness reflects in the statement (called akad or contract) before striking any deal of transaction. It is highly pronounced in statement of socalled Mudharabah, admitting to sharing method in the deal that there should be a fair share of profits and losses between two parties involved in the transaction.

Perceived fairness can also be attributed to non-interest calculation. Interest calculation is avoided, since it violates sense of fairness. A business has to face uncertain conditions, changes in supply and demand, unexpected events that make an exact forecasting impossible, and fluctuating exchange rate that make profit less certain, while accruing interests to pay is made certain and binding thought the business suffers losses. Even though the business gains some profit, the interest payment might overshadow or even surpass the profits it should have enjoyed.

\subsection{Marketing environment}

Culture within which an organization operates has an influential strength. Cultural environment forms one's social values, perception, attitude and behavior. Traditional values are part of culture which is the element of wider environment (Kotler \& Keller, 2012). The environment has ability to determine an individual's decisions relating to commercial consumption (Kotler \& Keller, 2012; Schiffman \& Kanuk, 2010). Cultural values are shaped in the early ages of the individual, are conveyed from one generation to another and tend to turn into long-term behavioral patterns in accordance with the cultural environment. Culture 


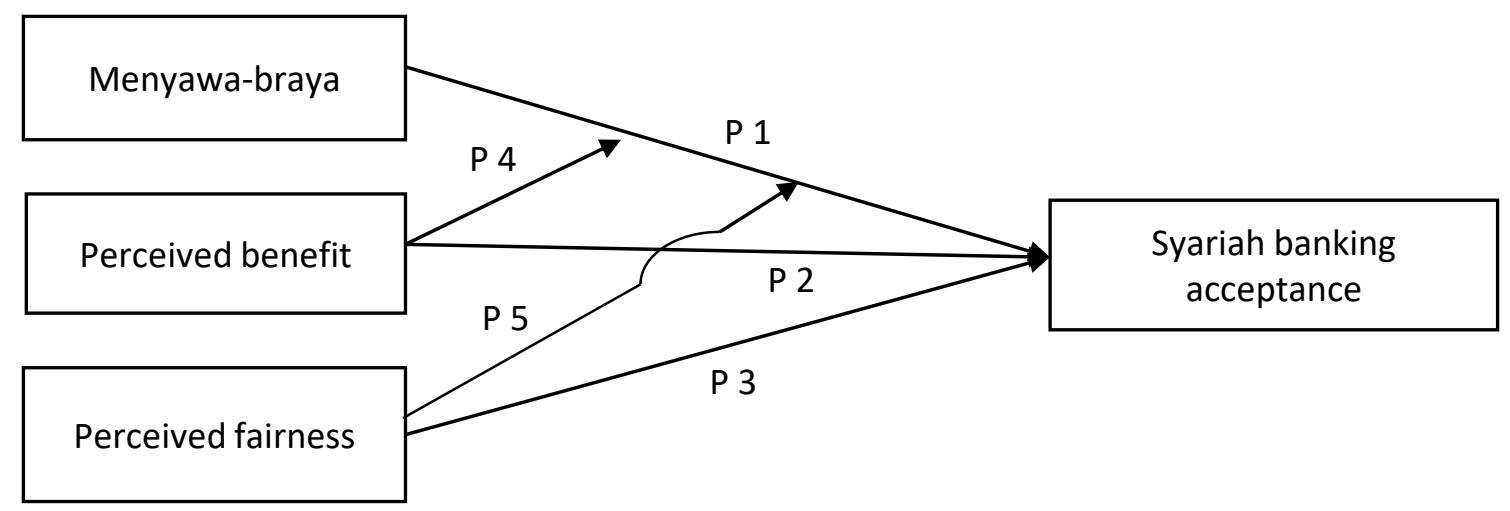

Figure 1. Relationship between variables

plays a key role in the formation of individuals' values, attitudes and behaviors. Religion always contains values. When these religious values are well maintained to keep society in unity and practiced in every day life, they might turn into a culture determining common attitude and behavior (Hofstede, 2001). In several areas, culture still holds a dominant role in affecting people's behavior. Bali serves as a good example for this. Balinese people still maintain traditional values that at later point serve as life guidance pertaining to proper attitude and behavior.

Studies of Kim, Se. and Kim, Su. (2015), Son et al. (2012), Aldosari (2012), Akturan and Tezcan (2012) provide evidence of the relationship between perceived benefit and acceptance. While study of Bos et al. (2015), Krishen et al. (2010), and Liu et al. (2015) have shown the significant effect of perceived fairness on the acceptance. On the other hand, the study believes that perceived benefit and fairness might moderate the relationship between menyama-braya and Syariah banking acceptance.

\section{P 1. Menyama-braya has a significant effect on Syariah banking acceptance.}

P 2. Perceived benefit has a significant effect on Syariah banking acceptance.

P 3. Perceived fairness has a significant effect on Syariah banking acceptance.

P 4. Perceived benefit has a moderating role in the relationship between menyama-braya and Syariah banking acceptance.
P 5. Perceived fairness has a moderating role in the relationship between menyama-braya and Syariah banking acceptance.

\subsection{Research conceptual model}

Research conceptual model created in problem formulation has been described previously. Figure 1 explains patterns of each relationship between these variables.

\section{METHODS}

\subsection{Data collection}

The sample covers Syariah banks' non-Moslem consumers in Bali. Their ages should be over 25 and their last educational background should be over senior high school to make sure of their familiarity of Syariah procedures, non-Moslem and Shariah bank consumers. Krosnick and Alwin (1989) show that age and education affect mature attitudes. Hurlock (1993) holds that early adult is between 18-40 years old. According to Santrock (2009), individulas within this range of ages are in the way of leaving egocentric to more emphatic way. To make them covered, this study applies convenient sampling. In Bali, there are nine Syariah banks with around 1.4 trillion of total assets. The present research intends to make contact to customers in these banks, explaining the purpose of the research and asking them to fill in the questionnaires. By convenient sampling method, the research selects the customers based on easiness and closeness. For sample size, it follows Malhotra (1993), 
suggesting that sample size for SEM can be calculated by multiplying the number of variables' indicators to 5 to 10 times.

\subsection{Instrument}

For menyama-braya, the study conducts content analysis, makes interviews with relevant experts and holds content validity. The study also asks customers judgment over the results. From this series of analysis, the study comes to three indicators for menyama-braya covering relationship, unity (harmony), and mutuality (Widagda, 2018). For perceived fairness, it follows Liu et al. (2015) with three indicators such as fair share, negative effect prevention, and fair rules. For the acceptance, it follows Chen et al. (2008) and is subject to adaptation to Shariah context after consulting to expert panel for content validity. While for perceived benefit, it follows Eurobarometer 73.1 with three indicators.

\subsection{Data analysis}

For data analysis, the study applies Smart PLS 3 that accommodates small sample size even in a rather complex model. It can handle the model that still lacks theoretical support or is exploratory in nature (Ghozali \& Latan, 2012). It also absorbs the complexity of reflective and formative nature found in one model (Hair et al., 2010).

\section{RESULTS}

The study assesses that menyama-braya does have a significant effect on Syariah banking acceptance. Widely held view that Syariah system is derived from Islam teachings has so far prevented the bulk of non-Moslem population from using Syariah banking services. Even though living in peace and harmony, religious practices are segregative in nature. It means that people of one religion do not have intention to enter into, interfere in, or make use of other people's religion practices or teachings. It is highly sensitive area that no one ever thought to fiddle with other people's religion system. Common ruling to ensure mutual respect and harmony is not to interfere other religions, but mind one's own religion. Menyawa-braya serves to bridge this psychological inhibition enabling
Balinese people to make contact much more easily to other people in different culture and religion.

The study assumes that monetary benefit does not have a significant effect on Syariah banking acceptance. The more monetary benefits that Syariah banking commonly offers is not a sufficient condition that can drive non-Moslem majority Balinese people to accept Syariah banking. Strong belief in one's own religion would not be easily swayed by more benefit switch. Religious belief is so strongly rooted that more benefit prospect would not suffice to effect some switch.

The study notices that perceived fairness might have a positive effect on Syariah banking acceptance even though slightly as fairness is contained in almost all belief systems, including Hindu. Fairness is a universal norm, and Hindu or other religion might find some alignment with Syariah system. Perceived fairness might slightly drive some of non-Moslem Balinese people to accept Syariah banking and apply its service for personal interests, as this feature is the only thing that they see fit between their religious belief system and Syariah philosophy.

The study expects that a more monetary benefit might have a moderating role in the relationship between local wisdom of menyawa-braya and Syariah banking acceptance. Big difference in monetary benefit enables consumers to make sound comparison and choice. A more monetary benefit might strengthen the effect of menyawa-braya on Syariah banking acceptance. The same thing also holds for perceived fairness on the relationship between menyawa-braya and Syariah banking acceptance. A more pronounced fairness in Syariah banking enables it to easily stand out among other banking types. By this way, differentiation and positioning are open wide.

\subsection{Future research}

Future research should include epistemic benefit, as it involves learning motive as a drive for acceptance. Other variables excluded in the model might be equally important. To detect and find these variables, qualitative researches are imperative, and sound results would follow especially as proven by quantitative study. 
Future research is also required to satisfy the inquiry as to effect strength of local wisdom, perceived benefit and perceived fairness on the acceptance that enables for interregional comparisons. Research in the area of Syariah banking in Bali setting should also take into account variables such as investing culture, ethnocentrism, religion identity and others in the model.

\subsection{Discussion}

In Bali case, local wisdom might have a direct effect on Syariah banking acceptance. In other regions outside Bali, this might not be the case. The moderating position of perceived benefit and fairness might swift into mediating posi- tion. It implies that local wisdom might have only indirect effect on the acceptance through another variables. The worse might be true that local wisdom only plays a moderating role, especially in areas where local wisdoms are not influential as in Bali.

In other scenario, one or more local wisdoms might be at play to effect the acceptance, as a region often has more than one local wisdom. The study of local wisdom effect is very important, since this kind of study is still rare but relevant in the context of Indonesia's regions which are rich in local wisdoms. The results will surely enrich management literature, particularly pertaining to local wisdoms.

\section{CONCLUSION}

Local wisdoms in an area where a business operationalizes can be capitalized on to heighten the acceptability of services or products originated from competing belief systems. Local wisdom of menyawa-braya might partially explain the Balinese people acceptance of Syariah banking. Perceived benefit and fairness might both moderate the relationship between menyawa-braya and the acceptance.

The study provides a model of different belief system derived service acceptance, especially in banking sector. The study suggests the model that is formed by three variables comprising a relevant local wisdom, perceived benefit and perceived fairness. Among them, the role of wisdom is considered as having the strongest effect on the acceptance. It should be followed by perceived fairness and then by perceived benefit, respectively.

As every region has various local wisdoms with varying effect degrees, the results might be different when applied in other regions. This warrants cautions as to generalizability issue, as every region has its own characteristics that might effect different results. Thus, the model is not fixed, subject to adaptation when applied to other region with different characteristics.

\section{ACKNOWLEDGMENTS}

The author would like to express gratitude to Syariah Banking in Bali for their consent and support for this research. The author owes them for data without which the research would be impossible. The author also thanks his colleagues from Halu Oleo University in Kendari who have provided useful insight and expertise. This research received no specific grant from any funding agency in the public, commercial, or not-for-profit sectors.

\section{REFERENCES}

1. Akturan, U., \& Tezcan, N. (2012)

Mobile banking adoption of

the youth market: Perceptions

and intentions. Marketing

Intelligence and Planning,
30(4), 444-459. https://doi.

org/10.1108/02634501211231928

2. Aldosari, B. (2012). User acceptance of a picture archiving and communication system
(PACS) in a Saudi Arabian hospital radiology department. $B M C$ Medical Informatics and Decision Making, 12(1). https:// doi.org/10.1186/1472-6947-12-44 
3. Bisnis Jabar (2011). Bank Syariah Di Bali Tumbuh 152\%. Retrieved from http://bandung.bisnis.com/ $\mathrm{read} / 20110823 / 5 / 82736 /$ banksyariah-di-bali-tumbuh-152

4. Blau, P. M. (1964). Exchange and power in social life (352 p.). New York: John Wiley.

5. Bos, C., Van Der Lans, I., Van Rijnsoever, F., \& Van Trijp, H. (2015). Consumer acceptance of population-level intervention strategies for healthy food choices: The role of perceived effectiveness and perceived fairness. Nutrients, 7(9), 7842-7862. https://doi. org/10.3390/nu7095370

6. Chen, R. S., Hsieh, K. K., \& Tsai, C. H. (2008). The Implementation of face recognition technology and its effect on e-quiz credibility. Asian Journal on Quality, 11(2), 125-136. https://doi. org/10.1108/15982681011075934

7. Davis, F. D. (1989). Perceived Usefulness, Perceived Ease of Use, and User Acceptance of Information Technology. MIS Quarterly, 13(3), 319-340. https:// doi.org/10.2307/249008

8. Emerson, R. M. (1962). PowerDependence Relations. American Sociological Review, 27(1), 31-41. https://doi.org/10.2307/2089716

9. Ghozali, I., \& Latan, H. (2012). Partial Least Square. Konsep, Teknik dan Aplikasi SmartPLS2.0 M3. Semarang: Badan Penerbit Universitas Diponogero.

10. Gwinner, K. P., Gremler, D. D., \& Bitner, M. J. (1998). Relational Benefits in Service Industries: The Customer's Perspectives. Journal of Academy of Marketing Science, 26(2), 101-104. https://doi. org/10.1177/0092070398262002

11. Hair, J. F., Black, W. C., Babin, B. J., \& Anderson, R. E. (2010). Multivariate Data Analysis: A global perspective. NJ: Pearson Education Inc., Upper Saddle River.

12. Hofstede, G. (2001). Culture's Consequences: Comparing Values, Behaviors, Institutions and Organizations across Nations. Australian Journal of Management, 27(1), 89-94. https://doi. org/10.1177/031289620202700105
13. Hurlock, E. B. (1993). Psikologi Perkembangan: Suatu pendekatan sepanjang rentang kehidupan (edisi kelima). Jakarta: Erlangga.

14. Kim, Se., \& Kim, Su. (2015). The role of value in the social acceptance of science-technology. International Review of Public Administration, 20(3), 305-322. http://dx.doi.org/10.1080/1229465 9.2015.1078081

15. Kompasiana (2014). Bank Syariah Bukan Ancaman untuk Perekonomian Bali. Retrieved from https://www.kompasiana.com/takutpada-allah/54f68172a3331198158b4eb1/ bank-syariah-bukan-ancamanuntuk-perekonomian-bali

16. Kotler, P., \& Keller, K. L. (2012). Marketing Management. New Jersey: Pearson Education Inc.

17. Krishen, A., Raschke, R., \& Mejza, M. (2010). Guidelines for Shaping Perceptions of Fairness of Transportation Infrastructure Policies: The Case of a Vehicle Mileage Tax. Transportation Journal, 49(3), 24-38. Retrieved from http://anjala.faculty.unlv. edu//Krishen_TJ_2010.pdf

18. Krosnick, J. A., \& Alwin, D. A. (1989). Aging and attitude change. Journal of Personality and Social Psychology, 57(3), 416-425. Retrieved from https:// pprg.stanford.edu/wp-content/ uploads/1989-Aging-and-AttChange-Krosnick-and-Alwin.pdf

19. Liu, I. F., Chen, R. S., \& Lu, H. C. (2015). An exploration into improving examinees' acceptance of participation in an online exam. Educational Technology and Society, 18(2), 153-165.

20. Malhotra, N. K. (1993). Marketing Research an Applied Orientation. New Jersey: Prentice Hall International Inc.

21. MES (2014). Bali Merupakan Penerima Terbesar Pembiayaan dari Bank Syariah. Retrieved from http://www.ekonomisyariah. org/4938/bali-merupakan-penerima-terbesar-pembiayaan-daribank-syariah/

22. Rokeach, M. (1973). The Nature of Human Values (p. 438). New York: Free Press.
23. Santrock, J. W. (2009). Perkembangan Anak. Jakarta: Erlangga.

24. Schiffman, L. G., \& Kanuk, L. L (2010). Consumer Behavior ( $9^{\text {th }}$ ed). Mason, Ohio: South-Western Thomas Learning.

25. Son, J., Sadachar, A., Manchiraju, S., Fiore, A. M., \& Niehm, L. S. (2012). Consumer adoption of online collaborative customer co-design. Journal of Research in Interactive Marketing, 6(3), 180-197. https://doi. org/10.1108/17505931211274660

26. Widagda, I. G. N. J. A. (2018). Pemgaruh citra koperasi, kepuasan anggota dan nilai-nilai adat terhadap kepercayaan anggota: Studi pada Koperasi di Bali (Dissertation). 